\title{
Botanical and soil studies in sandy vegetation of North Hungarian Great Plain
}

\author{
Gergely PÁPAY ${ }^{1}$ - Erika MICHÉLI ${ }^{2}$ - Eszter S.-FALUSI ${ }^{1}$ - Attila BARCZI ${ }^{3}-$ \\ Márta FUCHS ${ }^{2}$ \\ 1: Szent István University, Department of Botany, H-2100 Gödöllő, Páter Károly utca 1.; \\ E-mail: geri.papay@gmail.com \\ 2: Szent István University, Department of Soil Science H-2100 Gödöllő, Páter Károly utca 1. \\ 3: Szent István University, Department of Natural Concersation and Landscape Ecology H-2100 Gödöllö, Páter \\ Károly utca 1.
}

Keywords: Festuca vaginata, Festuca pseudovaginata, Danube-Tisza Interfluve

\section{Introduction}

During our research we examine the vegetation of sandy areas along the Danube. Pannonic sand steppes are habitats protected by Natura 2000 Habitat Directive. This habitat type occurs only in the Pannon Biogeographical Region in an extent of 48.000 ha (Haraszthy 2014). Sandy soils are generally nutrient-poor and their characteristic natural vegetation type is open sandy grasslands in the semi-arid areas (Molnár 2003). On the sandy areas of the Danube-Tisza Interfluve, environmental conditions allow Festuca vaginata to become a dominant species (Borhidi et al. 2012), and Festuca pseudovaginata has been recently described as a new taxon (Penksza 2003).

\section{Materials and methods}

Our study site is situated in north area of the Hungarian Great Plain (Vácrátót, Újpest, Szentendrei-sziget) on three vegetation types: 1) dominated by Festuca vaginata and 2) $F$. pseudovaginata, the latter was more frequent,. 3) closed grassland with $F$. wagnerii. Coenological sampling was carried out in June 2018 in 3 study sites, in quadrats of $2 \times 2 \mathrm{~m}$, in 6-6 relevés per vegetation type in every study site. Analyses of the relevés were based on cover scores of vascular plant species. Soil profiles were opened and described in every vegetation type, and soil samples for analysis were taken from every genetic soil horizon separately. Soil properties were compared by linear mixed models, where 'grassland type' was the fixed factor and 'site' was a random factor nested in 'grassland type'. Soil samples were taken from the depth of $0-15$ and $15-30 \mathrm{~cm}$. We examined soil parameters that might be connected to vegetation. Laboratory experiments were the follows: $\mathrm{pH}\left(\mathrm{H}_{2} \mathrm{O}\right.$, $\mathrm{KCl}$ ); $\mathrm{CaCO}_{3} ; \mathrm{Al}-\mathrm{P}_{2} \mathrm{O}_{5} ; \mathrm{Al}-\mathrm{K}_{2} \mathrm{O}$; humus (Turin method). Nitrogen availability, nitrogen forms ( $\mathrm{KCl}$ replaceable ammonium-nitrogen and nitrate) and total nitrogen content was measured. The three data types were subjected to the same cluster analysis technique: fusion algorithm was a combinatorial method (minimizing increase of variance) and the correlation was used as comparative function (Podani 2001).

\section{Results and discussion}

According to our results weakly developed humic sandy soils (Arenosols) were characteristic to the two open grassland types with a shallow A layer. It suggests that there have been open sandy grasslands in the area for a long time. In the closed F. wagnerii dominated grassland the soil type was described as brown earths (Cambisols) with deep 
$(120 \mathrm{~cm}) \mathrm{B}$ horizons, indicating that the formal vegetation were forest stands. Festuca species and vegetation types formed by them can be used as an indicator in studying landscape scale changes. The $\mathrm{pH}$ of the studied topsoil was around 8 in both sites, $\mathrm{CaCO}_{3}$ content varied between $3-5 \%$, which refers to a weak lime content. Humus content was very low in all cases $(<1 \%)$. Based on the soil laboratory analyses and field data, soils can be classified as regosols. Soil type was different in the two vegetation types: in $F$. vaginata dominated areas it was sandy skeletal soil, whilst in case of $F$. pseudovaginata it was brown soil which is characteristic in sandy forests (Stefanovits et al. 1999). As shown by the results of the LMM, four soil properties ( $\mathrm{pH}(\mathrm{KCl})$, total nitrogen-, AL$\mathrm{P}_{2} \mathrm{O}_{5}$ - and $\mathrm{AL}-\mathrm{K}_{2} \mathrm{O}-$ contents) of the upper 0-15 cm layer were different in case of the two Festuca-dominated grassland types, $F$. vaginata-dominated grasslands were characterized by higher values. In the $15-30 \mathrm{~cm}$ layer there was a significant difference in $\mathrm{pH}\left(\mathrm{H}_{2} \mathrm{O}\right)$ between the two grassland types; $F$. vaginata-dominated grasslands had higher $\mathrm{pH}$ values.

\section{Conclusions}

Species composition of the two grassland types were driven by environmental factors formed by local. F. vaginata dominated grasslands were characterised by higher total nitrogen, potassium, phosphorous and $\mathrm{pH}$ values compared to $F$. pseudovaginata grasslands. Higher nutrient content in the soil of Festuca vaginata dominated grasslands can be explained by the differences in the soil types as well as lower anthropogenic impact in Festuca vaginata dominated grasslands. Based on the classification results we can state that the studied Festuca species are good indicators for the soil properties. Festuca vaginata was typical on soils which have higher nitrogen and phosphorus content, while Festuca pseudovaginata was widespread on soils with lower nutrient content (Szabó et al., 2017).

\section{Acknowledgement}

The work was supported by NKFIH OTKA K-125423, Kiskunsági National Park, DunaIpoly National Park, Fertő-Hansági National Park, Budapest Waterworks, The Mayor's Office, Budapest.

\section{References}

Borhidi, A., Kevey, B., Lendvai, G. (2012): Plant communities of Hungary. Akadémiai Kiadó, Budapest.

Haraszthy, L. (ed.) (2014): Natura 2000 fajok és élöhelyek Magyarországon. (Natura 2000 species and habitats in Hungary) [in Hungarian]. Pro Vértes Közalapítvány, Csákvár: pp. 955

Molnár, Z. (2003): Dry sand vegetation of the Kiskunság. TermészetBÚVÁR Alapítvány Kiadó, Budapest: pp. 159

Penksza, K. (2003): Festuca pseudovaginata, a new species from sandy areas of the Carpathian basin. Acta Bot. Hung., 45, 356-372. p. https://doi.org/10.1556/abot.45.2003.3-4.11

Podani, J. (2001): SYN-TAX IV. Computer programs for data analysis in ecology and systematics. in: Feoli, E. \& Orlóczi, L. (eds.): Computer assisted vegetation analysis, Chapter 39: 437-452. https://doi.org/10.1007/97894-011-3418-7_39

Stefanovits, P., Filep, Gy., Füleky, Gy. (1999): Talajtan. (Pedology) [in Hungarian]. Mezőgazda Kiadó, Budapest: pp. 433

Szabó, G., Zimmermann, Z., Catorci, A., Csontos, P., Wichmann, B., Szentes, Sz., Barczi, A., Penksza, K. (2017): Comparative study on grasslands dominated by Festuca vaginata and F. pseudovaginata in the Carpathian Basin. Tuexenia 37: 415-429. 